\title{
TRANSBOUNDARY HAZE: ISLAM PROHIBITS DESTRUCTION OF EARTH ${ }^{1}$
}

\author{
Nurzawani Md Sofwan \\ Faculty Of Health Sciences, Universiti Teknologi MARA Sarawak, Malaysia \\ E-Mail: nurzawani@sarawak.uitm.edu.my \\ Hartini Mahidin \\ Faculty of Applied Sciences, Universiti Teknologi MARA Sarawak, Malaysia \\ E-Mail: tiniewinnie@sarawak.uitm.edu.my \\ Edmund Shah Tambi \\ Institute Aminuddin Baki Sarawak Branch, Malaysia \\ E-mail: edmundshah@iab.edu.my
}

\begin{abstract}
Recurring episodes of transboundary haze have been similarly to an annual event in Malaysia since the 1980's. Transboundary haze is typically haze caused by forest fires in Sumatra and Kalimantan, Indonesia which moves thousands of miles and encompasses neighboring regional countries. This is caused by human hands that continue to pursue unplanned development without taking into account the aspect of environmental sustainability. This study looks into and the understanding of recurring occurrences of transboundary haze in Sarawak. From the perspective of Islam, by making the Holy Quran as the absolute source of reference, God forbids the destruction of nature and calls upon mankind to do good not only to other humans and animals but also to the environment. Human beings are endowed with a great mind that can guide them to make and do the right thing, thus, various efforts need to be taken into consideration and be done collectively amongst the ASEAN countries in a joint effort towards reducing or preventing continuous episodes of transboundary haze within the region.
\end{abstract}

Keywords: Transboundary Haze, Air Pollutant Index, Forest Fires, Air Pollution

\section{INTRODUCTION}

Haze is a phenomenon of air pollution caused by particulates or fine particles

${ }^{1}$ Acknowledgment is extended to the Natural Resources and Environment Board (NREB) of Sarawak for providing the authors with invaluable air quality data. Our appreciation and thank you is also extended to Universiti Teknologi MARA (UiTM) of the Sarawak Branch for their continuous support in conducting this study. Last but not least is that the authors would like to record sincere appreciation to the Konferensi Antarabangsa Islam Borneo (KAIB) XI 2018 held in Pontianak as the paper was selected to be presented. 
which cannot be seen by the naked eyes that are suspended in the atmosphere in high concentrations. Among the natural factors that lead to formation of haze are natural phenomenon such as volcanic eruptions, soil dust and sea breezes that contain salt. On the other hand, some of the man-made factors arising from the release of pollutants are from motor vehicles, open burning, emissions from industries through chimneys, land development and construction works. However, the high concentration of haze that occurred in Malaysia particularly in 1983, 1997, 2005, 2013 and 2015 are called transboundary haze due to the fact that the main source came from the open burning carried out at large-scale oil palm plantations mainly in Sumatra and Kalimantan (Afroz et al., 2003). These findings were based on studies carried out and the findings showed that the rate of the formation of haze had a positive correlation with sulfur, whereby the occurrence of forest fires or biomass materials will release sulfur and potassium into the air.

In 2002, the Association of South East Asian Nations (ASEAN) had agreed to sign an agreement on cross-border haze pollution and to find ways to prevent re-occurrence of forest fires that will lead to formation of haze. Indonesia, however, did not ratify the agreement (ASEAN, 2002). The occurrences of haze will cause various problems in terms of 1) forest fires that leads to emissions of greenhouse gasses, the destructions of the biodiversity and habitat for the flora and fauna, 2) increases health risks especially to the elderly, children and the sickly people, 3) negative effects on the economic and tourism industries, and 4) threatens diplomatic relation between neighbouring countries (Glover et al., 2003; Narayanan; 2002). It could worsen if the occurrence of haze leads to high biomass combustion causing changes in earth temperature and eventually global climate (Huang et al., 2013). Thus, this study contributes to the understanding of the occurrence of transboundary haze in the State of Sarawak with reference to the Islamic prohibition as mentioned in the Holy Quran.

Malaysia adopts a computational system called the Air Pollutant Index (API) system. This index system was developed by the Department of Environment (DOE) of Malaysia and it was translated into API readings as in Table 1 to facilitate relaying of information and understanding to the community at large. The API reading is developed in easily understood ranges of values as a mean of reporting the quality of air instead of using the actual concentration of air pollutants. The higher the API value, the higher the level of air pollution where it is used to inform the public about the health status of the air quality as stipulated in the National Haze Action Plan. The reading involves measuring 5 types of air pollutants: carbon monoxide $(\mathrm{CO})$, sulfur dioxide $\left(\mathrm{SO}_{2}\right)$, ozone 
$\left(\mathrm{O}_{3}\right)$, nitrogen dioxide $\left(\mathrm{NO}_{2}\right)$ and fine particulate matter with diameter size less than $10 \mu \mathrm{m}\left(\mathrm{PM}_{10}\right)$. The Malaysian API system closely follows the Pollutant Standard Index (PSI) developed by the United States Environmental Protection Agency (USEPA).

Table 1. Air Pollutants Index (API)

\begin{tabular}{|c|c|}
\hline API & Status \\
\hline $0-50$ & Good \\
\hline $51-100$ & Moderate \\
\hline $101-200$ & Unhealthy \\
\hline $201-300$ & Very Unhealthy \\
\hline$\varnothing 301$ & Hazardous \\
\hline
\end{tabular}

Source: Department of Environment

Sarawak had the worst impacts of haze across the country by recording a percentage of $23.8 \%$ of the unhealthy days (Afroz et al., 2013). The state of Sarawak, which borders on Kalimantan, allows it to receive a high amount of haze brought by wind factor. Therefore, the National Resources and Environment Board of Sarawak (NREB) is committed to develop three air quality monitoring stations focusing on border areas with Indonesia, namely Tebedu, Lubok Antu and Lawas as shown in Figure 1. On top of that, the monitoring of air quality mainly in the residential and industrial area is under direct supervision of Department of Enviroment (DOE). Based on the available data and the analysis process, this work provides the explanation of the detail occurrence of the haze, its impacts to human healthiness and the responses of human being to the transboundary haze based on religious teaching, especially Islam for the seeks of better initiatives. 


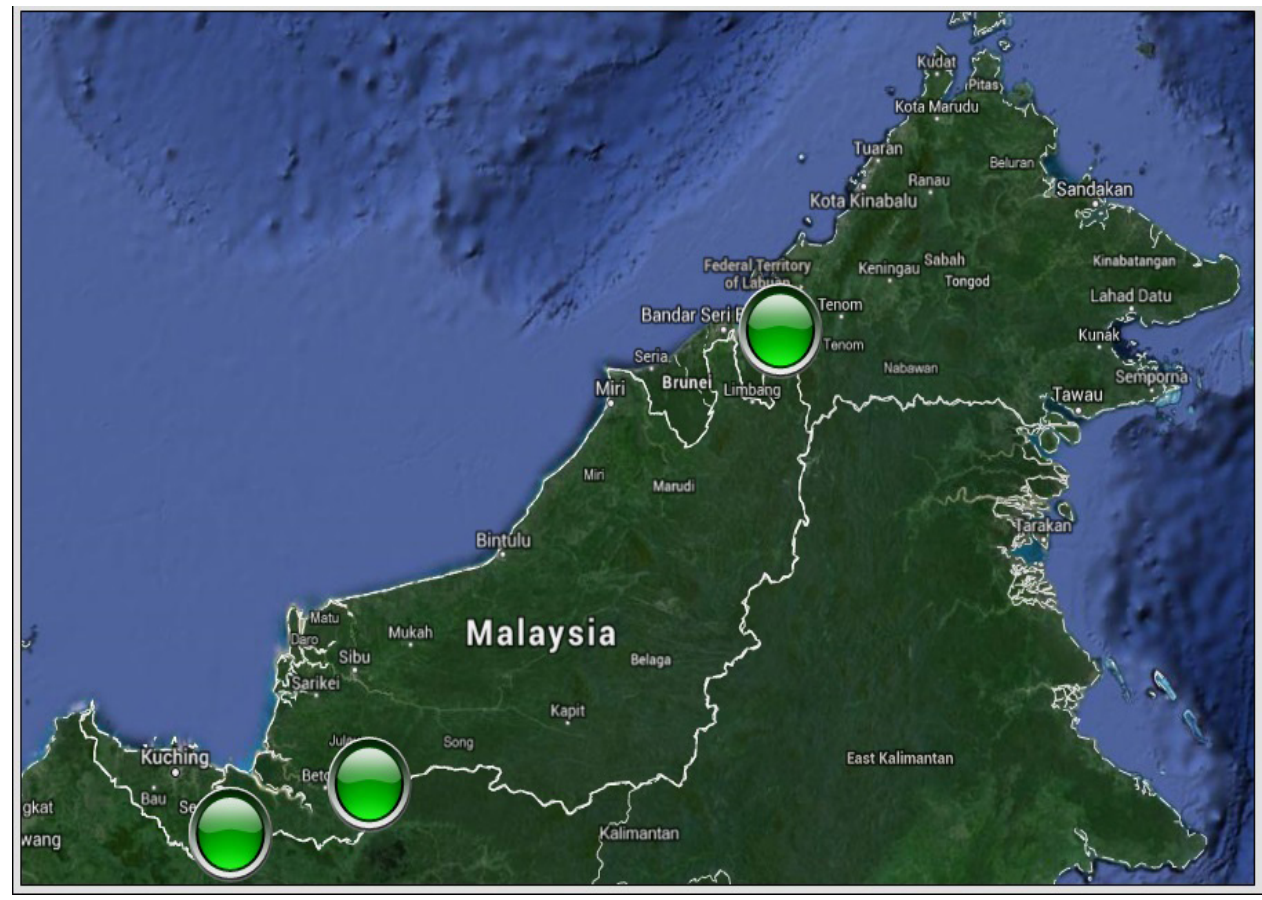

Figure 1 . Three air quality monitoring stations under NREB supervision

\section{THE CHRONOLOGY ON HAZE OCCURRENCES IN SARAWAK}

Sarawak recorded the worst episode of haze with the highest API reading of 860 in 1997 which caused the government to declare a state of emergency for 10 days from September 19 to 28,1997 . This transboundary haze was due to forest fires in Kalimantan as a result of combustion of biomass activities in agriculture. It was exacerbated by the El Nino factor that affected the rainfall which caused a long dry season. The effects of the horrendous haze of 1997 caused 10,000 people to get treatment due to illness caused by haze such as breathlessness, eye sore and sore throat. Smoke, dust and gases emitted from this biomass combustion was carried by the Southwest monsoon from Sumatra and Kalimantan to Malaysia. The haze was also trapped by mountain systems and ranges. According to DOE, the top air pollutant parameter for the worst haze in Southeast Asia in 1997 was $\mathrm{PM}_{10}$. A haze study conducted by Anwar et al., (2010) in Riau in 2006 found that the highest concentrations of $\mathrm{PM}_{10}$ and $\mathrm{O}_{3}$ were during the haze season as compared to the non-haze days.

In August of 2006, several areas in Kuching, Sibu, Samarahan, Sarikei, Sri Aman, Petra Jaya and Bintulu recorded unhealthy API readings. The air quality worsened in late September and by early October of 2006, the town of Sri Aman recorded an APIs of 224 on 6 October 2006. Several series of haze emanating from transboundary haze occurred from May to September 2011 that was a result of forest fires in Central Sumatra and Kalimantan during the 
dry season. Haze once again recurred in 2012 from June to August and this time around it was exacerbated by mangrove fires in Miri as well as forest fires in the northern and central region of Sumatra (DOE, 2018).

Several divisions in Sarawak recorded an extremely unhealthy API reading from July to September 2014. In Sibu for example, a reading of 270 was recorded on July 28, 2014. In several states of Peninsular Malaysia in the same year, severe unhealthy concentration of haze was also recorded. While in 2015, during the Southwest monsoon season, Malaysia once again received a slump in air quality due to the opening of large agricultural fields that led to forest fires in Sumatra and Kalimantan. On September 15, 2015, 34 areas recorded unhealthy air quality status for the first time in Malaysia's history since 1997. Several schools around Kuching, Samarahan, Putrajaya, Negeri Sembilan and Malacca were ordered to be close. (DOE, 2018). Figure 2 shows the concentration of $\mathrm{PM}_{10}$ as recorded at Tebedu station a small town in Sarawak bordering Kalimantan, Indonesia.

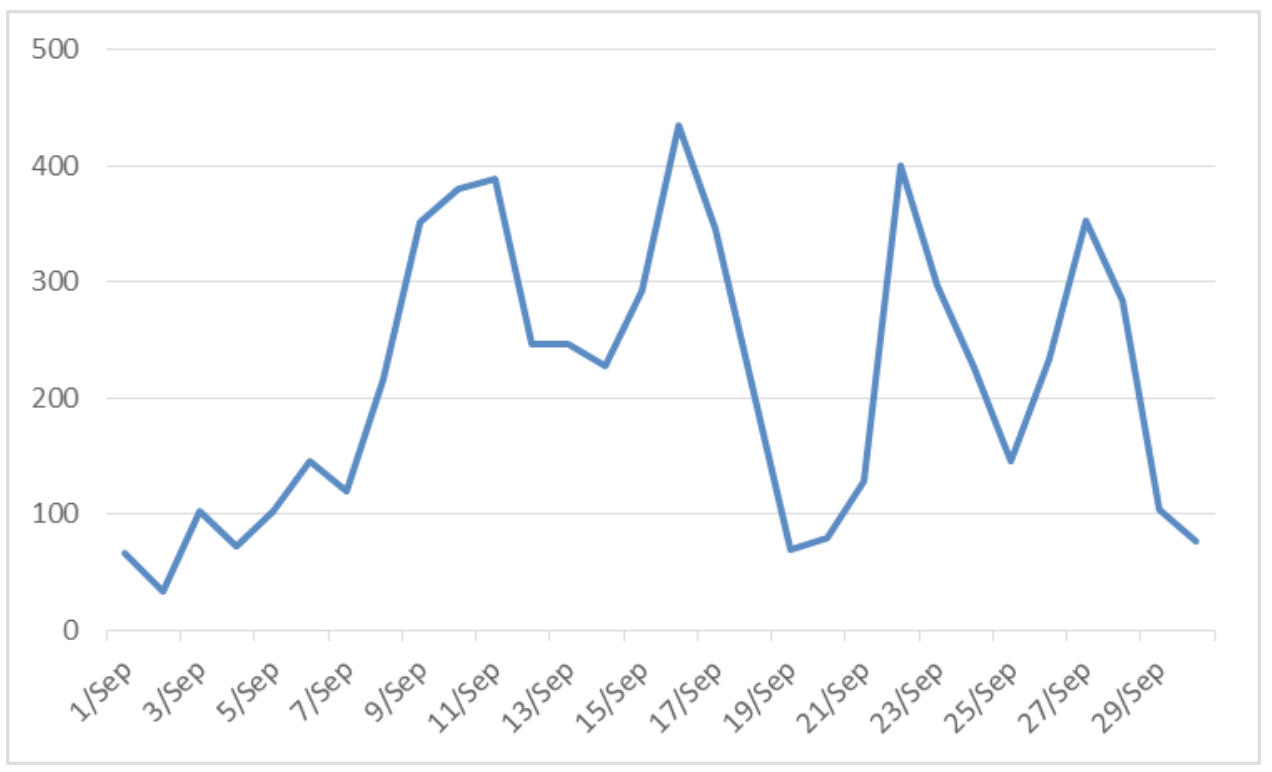

Figure 2. $\mathrm{PM}_{10}$ concentration in Tebedu in September 2015

\section{NUMBER OF HOTSPOTS}

A hotspot represents an area of $1 \times 1 \mathrm{~km}^{2}$ which means forest fires as large as the size of the pixel shown. A total of 3918 hotspots were detected in Kalimantan, Indonesia, Sarawak in September 2015 as shown in Figure 3. During the same period, 2691 hotspots were detected in Sumatra and 10 in Sarawak. Through the image of the National Oceanic Atmospheric Association (NOAA) 18, the highest number of hotspots was detected on September 22, 2015, where 479 fire events were detected in Kalimantan. Malaysia took some very important 
precautionary measures by reminding people not to conduct open burning which could have aggravated the hazy conditions. The advice was done when an increase in hotspots was spotted across the country.

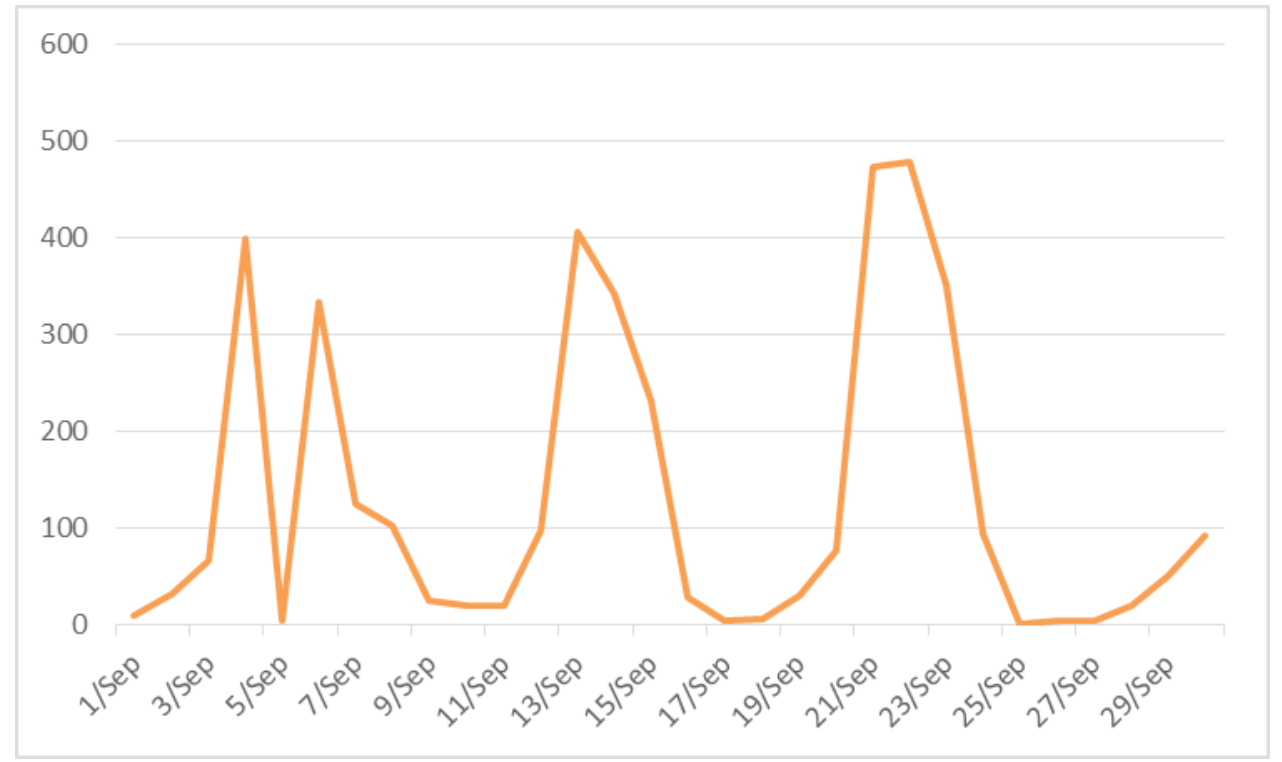

Figure 3. Number of hotspots in Kalimantan in September 2015

The Regional Haze Map as issued by the ASEAN Specialized Meteorological Centre (ASMC) on $8^{\text {th }}$ September 2015 as shown in Figure 4, shows the thick and medium structured haze smog movement from the fire areas in Kalimantan, Indonesia to the West of Sarawak, whereas thick and moderately formed haze structure from fire areas in Central and Southern Sumatra, Indonesia is found to have covered most of the West Coast of Peninsular Malaysia.

\section{IMPACT OF AIR POLLUTION ON HUMAN HEALTH}

Exposure to air pollution, either in the short or long term, does affects human health. During the occurrence of haze, sunlight will be dispersed by suspended particles, causing harmful bacterial and viral reproduction (Beardsley et al., 1997). In addition, suspended particles contain chemical and organic compositions such as Polycyclic Aromatic Hydrocarbon (PAH) known to be a form of cancer agent. Haze not only affects the quality of human health but affects economic and school activities. This is because in many incidences, schools will be directed to close by the Malaysia Ministry of Education, if the API level reaches a dangerous level. In this unhealthy condition, affected school going children have been reported to be breathing faster and thus more of the unhealthy particles will be inhaled as compared to adults. Another 
related issue would also be inadequate (perhaps incomplete) immunization levels given to the children and adults concerned (Mohamad et al., 2016).

A study conducted by Nasir et al., (2000) showed that the haze of 1997 had caused 285, 227 cases of asthma attacks, 118, 804 cases of bronchitis in children, 3889 chronic cases of bronchitis among adults, 2003 related cases of individuals being detained in hospital due to respiratory problems, and 26, 684 emergency treatment cases. Indirectly, medical costs increased significantly during that historical hazy season. The number of outpatients seeking treatments at hospitals in Kuching, Sarawak also increased from two to three times higher than normal during that severe haze phenomenon that struck the country in 1997. In addition to respiratory problems, infectious cases such as conjunctivitis also increased dramatically during the haze season. In Selangor for example, the increase was recorded, from only 207 cases in June of that year to 3496 cases in October. The same pattern was also recorded in Sarawak where it was closely linked to the increase of API (Afroz et al., 2003).

\section{THE HOLY QURAN PROHIBITS DESTRUCTION OF EARTH}

Haze is categorized as man-made damage because its main cause is from uncontrolled human activities. Mohamad (2005) described the act of polluting air like open burning is categorized as a nuisance to mankind as its unhealthy effects enter the airspace in neighbouring countries. The Islamic school of thoughts of scholars like Maliki and Hanbali assert that any form of nuisance activities and also purposeful destructions caused by mankind must be stopped immediately. There are many Quranic verses that clearly explain about the need to protect the environment such as the order of not doing damage to the earth, the effects and consequences of human acts, the rewards for the arrogance and the reprisal of the corrupt. Among the surahs and verses of the Quran mentioned in relation to the environment are provided below.

1) Order not to do damage to the earth

"...and when it is said unto them; Do not make mischief in the land, they say: "We are the only ones who make good".

Surah Al-Baqarah verse 11

2) Cause and effect of human destruction

"There was visible damage on land and in the sea due to human hands; Allah wishes them to taste some of their evil deeds, that they may return 
(to the right path)".

Surah Ar-Rum verse 41

3) Requital to those who destroy Allah's Creation

“..and those who breaks God's (covenant) after it has been decided upon, thus God commanded to be reattached, yet they are mischievous and continue to make destruction on earth - (Allah) be cursed upon them to those who do evil and they will be rewarded with the worst of days in the Hereafter".

Surah Ar-Ra'd verse 25

4) Comparisons between believers and those who are cruel to the environment

"... then should there be among the people that had been destroyed before you, are those who are excesses of reason that forbid their people from evil deeds on earth but, what a pity..! There is none to forbid except a few, those whom We have saved amongst them, and those who do not forbid, are the ones who choose luxury bestowed to them (over faith) and they are the ones who are sinners".

Surah Hud verse 116

Based on the above arguments and proofs from the Holy Quran, it is clear that Islam staunchly forbids humanity to make damage to the earth because the consequences are not confined within our country but can also do harm to other areas such, thus the occurrences known as cross-border haze. However, sadly, very few individuals are willing to partake the effort and responsibility in protecting the environment and also preventing others from damaging the environments around us. Development, of course, cannot be separated from our present life. However, human wisdom in balancing development and the preservation of the environment around us is important in ensuring the continuous survival of future generations.

The need for this balance in the environment correlates with the concept of Al-Mizan as emphasised by the Islamic teaching. According to Halim and Akhir (2016), based on this concept, God has given roles and responsibilities to all of His creation. If the roles or responsibilities entrusted are not done, then this natural system Allah has created will change. The system that Allah has created will not be affected if greed and human exploitation of nature for the purpose of development is avoided and controlled. This is because the system will form an equal balance through order and harmony in nature that 
will complement each other (Akhir, 2004).

\section{CONCLUSION}

Various efforts have been introduced since 1995 to formulate plans to prevent peat and forest fires in the region through improved policy, continuous enforcement and state of the art monitoring mechanisms. However, this effort requires strong co-ordination and cooperation from all countries involved within the Southeast Asian region to ensure all the planned efforts that have been agreed upon being successfully implemented. The work also suggests that the efforts of encouraging the participation of more individuals on reducing the transboundary haze need the support by religiously based initiatives. This is in line with the command of Allah to humanity preventing man from doing any damage to the earth that human beings should therefore act as a caliph and take responsibility for what they do to the environment around. God has entrusted this world of ours for us to save and keep and that is what the people have to do for the benefit of humanity today and tomorrow.

This work recognizes that in embracing the Industrial Revolution 4.0, Malaysia is in full force in taking challenges of the new era with the implementation of digital technology in many aspects. The DOE has introduced a MyIPU smartphone application for Air Pollutants Index (API) as part of the new government's ongoing commitment to improve service quality for the people. The apps, which can be downloaded via all smartphones applications platform aims to inform the public on the current status of API readings throughout the country. In addition, all weather information, hotspots, rainfalls and haze-related statistics are also available directly from relevant websites. This initiative is intended to help people to have early warning awareness so that they are able to take immediate responses as necessary.

\section{BIBLIOGRAPHY}

Afroz, R. Hasaan, M. N., \& Ibrahim, N. A., (2003). Review of Air Pollution and Health Impacts in Malaysia. Environ. Research, 92, 71-77.

Akhir, N. S. M. (2004). Rohani Manusia dan Alam Sekitar dari Perspektif Islam. Jurnal IKIM, 12 (2).

Anwar, A., Juneng, L., Othman, M. R., Latif, M. T., (2010). Correlation between hotspots and air quality in Pekan Baru, Riau, Indonesia in 20062007. Sains Malaysia. 39, 169-174.

ASEAN, (2002). ASEAN Agreement on Transboundary Haze Pollution. Asso- 
ciation of South East Asian Nations Secretariat. Jakarta.

Beardsley, R., Bromberg, P. A., Costa, D. A., Devlin, R., Dockery, D. W., Frampton, M. W., Lambert, W., Samet, J. M., Speizer, F. E., \& Utell, M., (1997). Smoke Alarm: Haze From Fires Might Promote Bacterial Growth. Sci. Am. 24-25.

DOE, Department of Environment., (2018). Kronologi Episod Jerebu di Malaysia. Retrieved May 28, 2018, from DOE Portal: https://www.doe. gov.my/portalv1/en/info-umum/info-kualiti-udara/kronologi-episod-jerebu-dimalaysia/319123.

Glover, D., Jessup, T., Banks, G., (2003). Indonesia's fires and haze: the cost of catastrophe. Review of Indonesian and Malaysian Affairs. 37, 150-152.

Halim, I. A. \& Akhir, N. S. M., (2016). Tafsir Ayat-Ayat al-Quran Berkenaan Penjagaan Alam Sekitar. Afkar. Vol. 18 (1), 91-130.

Huang, K., Fu, J. S., Hsu, N. C., Gao, Y., Dong, X., Tsay, S. C., Lam, Y. F., (2013). Impact Assessment of Biomass Burning on air quality in Southeast and East Asia during BASEASIA. Atmos. Environ. 78, 291-302.

Mohamad, A. B., (2005). Undang-undang dan Pengurusan Alam Sekitar Menurut Islam. Malaysian Journal of Environmental Management, 6, 107-124.

Mohamad, N., Latif, M. T., \& Khan, M. F., (2016). Source Apportionment and Health Risk Assessment of $\mathrm{PM}_{10}$ in a Naturally Ventilated School in a Tropical Environment. Ecotoxi. And Environ. Safety, 124, 351-362.

Narayanan, S. (2002). Assessing the economic damage from Indonesian fires and the haze: a conceptual note. Singapore Economic Review. 47, 229-241.

Nasir, M. H., Choo, W. Y., Rafia, A., Md., M. R., Theng, L. C., Noor, M. M. H., (2000). Estimation of Health Damage Cost For 1997-Haze Episode in Malaysia Using the Ostro Model. Proceedings Malaysian Science and Technology Congress, 2000. Confederation of Scientific and Technological Association in Malaysia (COST- AM), Kuala Lumpur.

WHO, World Health Organization., (1998). Report of the Bioregional Workshop on Health Impacts of Haze Related Air Pollution. Manila: The Philippines. 